\title{
Role of Substrate and Calcium in Neurite Retraction of Leech Neurons following Depolarization
}

\author{
M. Diana Neely \\ Department of Pharmacology, Biocenter, University of Basel, $\mathrm{CH}-4056$ Basel, Switzerland
}

The aim of these experiments was to analyze how depolarization influences neurite outgrowth in leech neurons and what role the substrate and $\mathrm{Ca}^{2+}$ play in this response. Neurons in culture were exposed to $60 \mathrm{~mm}$ extracellular $\mathrm{K}^{+}$for $30 \mathrm{~min}$, which induced retraction of a subset of neurites growing on extracellular matrix substrate (ECM), a response comparable to that observed after electrical stimulation (Grumbacher-Reinert and Nicholls, 1992). After normal medium had been restored, the neurites continued to retract for about $1 \mathrm{hr}$ to approximately $80 \%$ of the total starting neurite length. Retraction was reversible and regrowth began after the cells had been in normal medium for about 3 hr. Similar depolarization-induced neurite retraction was observed in both Retzius and anterior pagoda cells. Retraction was inhibited by raised extracellular $\mathbf{M g}^{2+}$, suggesting a mechanism dependent on calcium. The effect of high $\mathrm{K}^{+}$on neurite outgrowth was also influenced by the substrate on which the cells were plated. Cells plated on concanavalin A (ConA) did not retract but continued to extend processes during exposure to high $K^{+}$. To understand the different behavior of cells grown on ECM and ConA, the morphology of growth cones was analyzed by scanning electron microscopy. The growth cones of cells grown on ECM and exposed to high $\mathrm{K}^{+}$revealed retraction of lamellipodial and filopodial structures. On ConA, however, no differences were observed between growth cones of cells exposed to high $\mathrm{K}^{+}$ and those of control cells. These results demonstrate the importance of substrate molecules in the responses of growth cones to depolarization and therefore in the differentiation of neurons.

[Key words: leech, neurons, depolarization, substrate, calcium, neurite retraction, growth cone]

A key question in neural development concerns the mechanisms that mediate specificity of axonal outgrowth. In many instances, initial axonal outgrowth is excessive and imprecise, giving rise to an immature network, which must then be remodeled through elimination of superfluous axons to acquire the adult form (Purves and Lichtman, 1980).

The first evidence for local elimination of neuronal processes

Received July 6, 1992; revised Sept. 23, 1992; accepted Oct. 1, 1992.

I thank my colleague Dr. J. Nicholls for his unfailing support throughout the work and critical comments on the manuscript, Dr. W. Adams for reading of the manuscript, Drs. W. Adams and D. Walz for advice on the statistical analysis, and Mr. P. Bättig for photography. This work was supported by Grant 3127814.89 from the Swiss Nationalfonds.

Correspondence should be addressed to M. Diana Neely, Biocenter, University of Basel, Department of Pharmacology, Klingelbergstrasse 70, CH-4056 Basel, Switzerland.

Copyright (C) 1993 Society for Neuroscience $0270-6474 / 93 / 131292-10 \$ 05.00 / 0$ came from studies of the developing neuromuscular junction (reviewed in Van Essen, 1982). It is now clear, however, that this phenomenon occurs widely in PNS as well as in CNS of vertebrates (Innocenti, 1981; Mariani and Changeux, 1981; Heathcote and Sargent, 1985). A growing body of evidence indicates that process elimination is also important for neural development in invertebrates (Truman and Reiss, 1976; Pipa, 1978; Goodman et al., 1981; Levine and Truman, 1982; Levine et al., 1986; Lnenicka and Murphey, 1989). Thus, several types of neurons of the developing leech grow in many directions and then retract processes (Kuwada and Kramer, 1983; Wallace, 1984; Glover and Mason, 1986; Gao and Macagno, 1987a,b; Jellies et al., 1987; Loer et al., 1987; Baptista and Macagno, 1988; Wolszon and Macagno, 1992).

In vivo studies in vertebrates and invertebrates have indicated that one of the signals influencing axonal outgrowth is neural activity (Wiesel and Hubel, 1963, 1965; Hubel and Wiesel, 1970; Lnenicka and Murphey, 1989; Budnik et al., 1990; Shatz, 1990). Similar observations have been made in vitro with cells in defined culture conditions (Anglister et al., 1982; Cohan et al., 1985; Cohan and Kater, 1986; Fields et al., 1990; GrumbacherReinert and Nicholls, 1992) where the effects of electrical activity can be mimicked by depolarization with raised extracellular K+ (Anglister et al., 1982; Campenot, 1984; Sussdorf and Campenot, 1986; Mattson et al., 1988; Robson and Burgoyne, 1989). In some systems influx of $\mathrm{Ca}^{2+}$ into the growth cone is involved in depolarization-induced changes in neurite outgrowth (Anglister et al., 1982; Cohan et al., 1987; Mattson and Kater, 1987; Kater et al., 1988; Mattson et al., 1988). In other systems, however, a voltage-dependent influx of $\mathrm{Ca}^{2+}$ does not affect neurite extension (Campenot and Draker, 1989; Usowicz et al., 1990; Garyantes and Regehr, 1992).

Extrinsic cues such as molecules in the extracellular matrix (ECM) are also potent regulators of neuronal morphology in vivo (for reviews, see Sanes, 1989; Reichardt and Tomaselli, 1991). Neurites of cultured cells are influenced by the substrate with respect to their growth rate, branching pattern, and morphology (Letourneau, 1979; Carbonetto et al., 1983; Chiquet and Acklin, 1986; Chiquet and Nicholls, 1987; Hammarback et al., 1988; Wehrle and Chiquet, 1990; Rivas et al., 1992). Neurites of leech cells plated on ECM are slender, long, and straight, rarely branch, and their growth cones are small. On concanavalin A (ConA), the processes are curved, highly branched, and fasciculated, and their growth cones are broad and flat (Chiquet and Acklin, 1986; Chiquet and Nicholls, 1987; Grumbacher-Reinert, 1989). Leech Retzius cells grown on ECM respond with neurite retraction following electrical stimulation, whereas this response is absent in cells plated on ConA (Grumbacher-Reinert and Nicholls, 1992). In addition to differences in neurite out- 

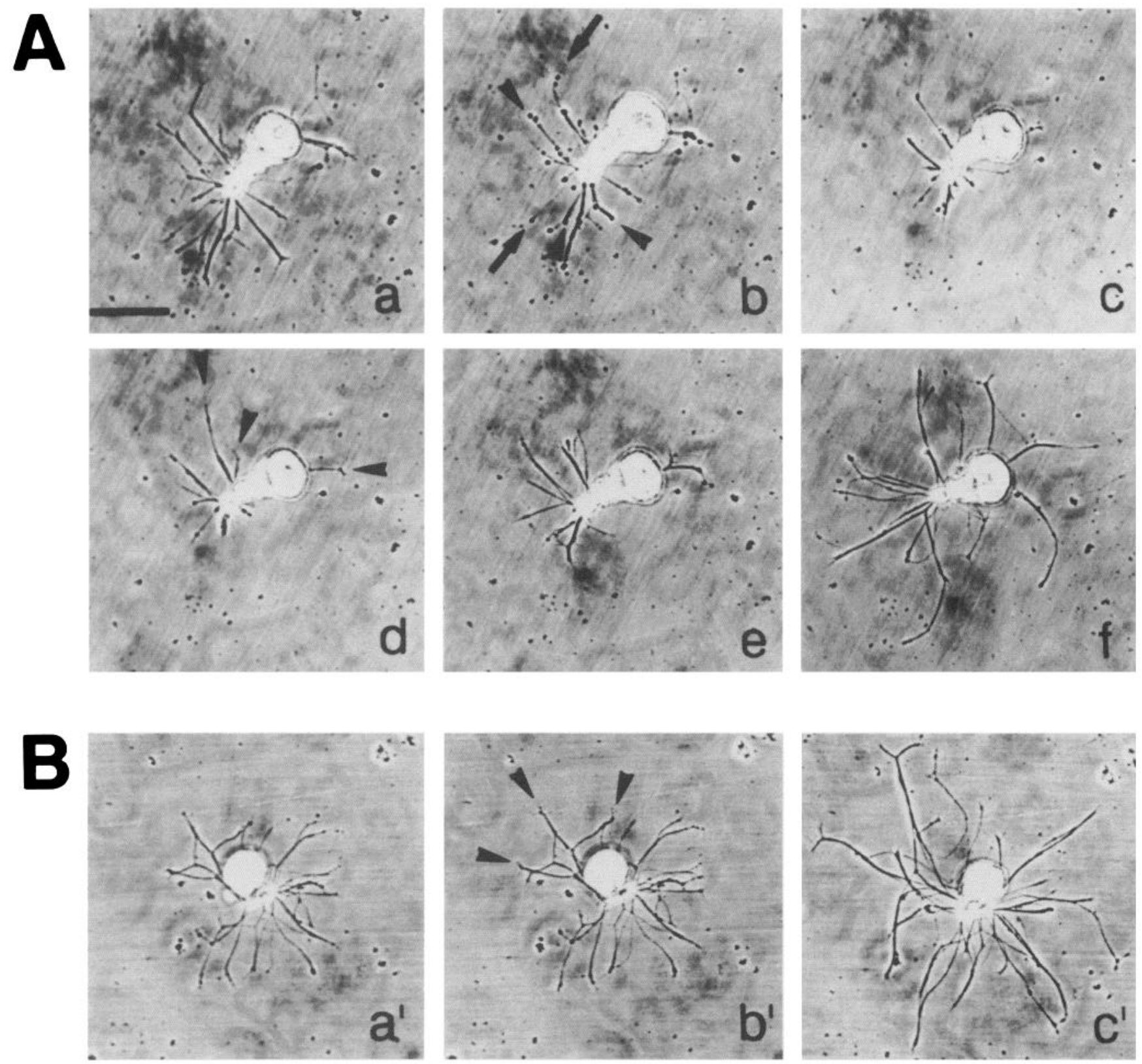

Figure 1. Depolarization induces neurite retraction in leech neurons. $A$, A leech Retzius cell $1 \mathrm{~d}$ after plating on ECM (a). After 30 min exposure to high $\mathrm{K}^{+}$medium $(b)$, some of the neurites had retracted extensively $(b$, arrowheads), while others showed partial retraction and rounding up of their growth cones $(b$, arrows). After return to normal medium, retraction continued during the first $1.5 \mathrm{hr}(c)$. After $3.5 \mathrm{hr}$, however, the cell started growing again $(d$, arrowheads) and showed recognizable regrowth after $5.5 \mathrm{hr}(e)$. The cell had extended neurites to more than the total starting neurite length after $22.5 \mathrm{hr}$ of recovery $(f)$. B, A Retzius cell $1 \mathrm{~d}$ after plating on ECM $(a)$. No neurite retraction or rounding up of growth cones was observed during the 30 min exposure to $\mathrm{Na}^{+}$control medium, but rather the cell continued to extend its neurites $\left(b^{\prime}\right.$, arrowheads). Extensive growth was observed after $22.5 \mathrm{hr}$ in normal medium (c). Scale bar, $100 \mu \mathrm{m}$.

growth, the expression of $\mathrm{Ca}^{2+}$ channels on the surface of leech neurons depends on the substrate. Retzius cells plated on ECM show strong voltage-dependent $\mathrm{Ca}^{2+}$ currents in their neurites, while those plated on ConA have few $\mathrm{Ca}^{2+}$ channels in the processes (Ross et al., 1987, 1988).

The present experiments were designed to analyze the role the substrate plays in depolarization-induced neurite retraction in cultured leech cells. The results show that membrane depolarization by high extracellular $\mathrm{K}^{+}$induces changes in growth cone morphology and neurite retraction in cells plated on ECM. These responses were dependent on extracellular $\mathrm{Ca}^{2+}$. In con- trast, the morphology of the growth cones and growth of cells on ConA were not altered by the same treatment.

\section{Materials and Methods}

Cell culture. The techniques for the identification, isolation, and culture of neurons from the leech CNS have been described in detail elsewhere (Fuchs et al., 1981; Dietzel et al., 1986). In brief, leech (Hirudo medicinalis) ganglion chains were dissected out and pinned in a Sylgardcoated dish (Pluess Staufer AG, Oftringen, Switzerland). The capsules enveloping the ganglia were torn open with forceps. The ganglia were incubated with collagenase/dispase $(2 \mathrm{mg} / \mathrm{ml}$; Essex Chemie AG, Lucerne, Switzerland) in L-15 medium (GIBCO) supplemented with gen- 


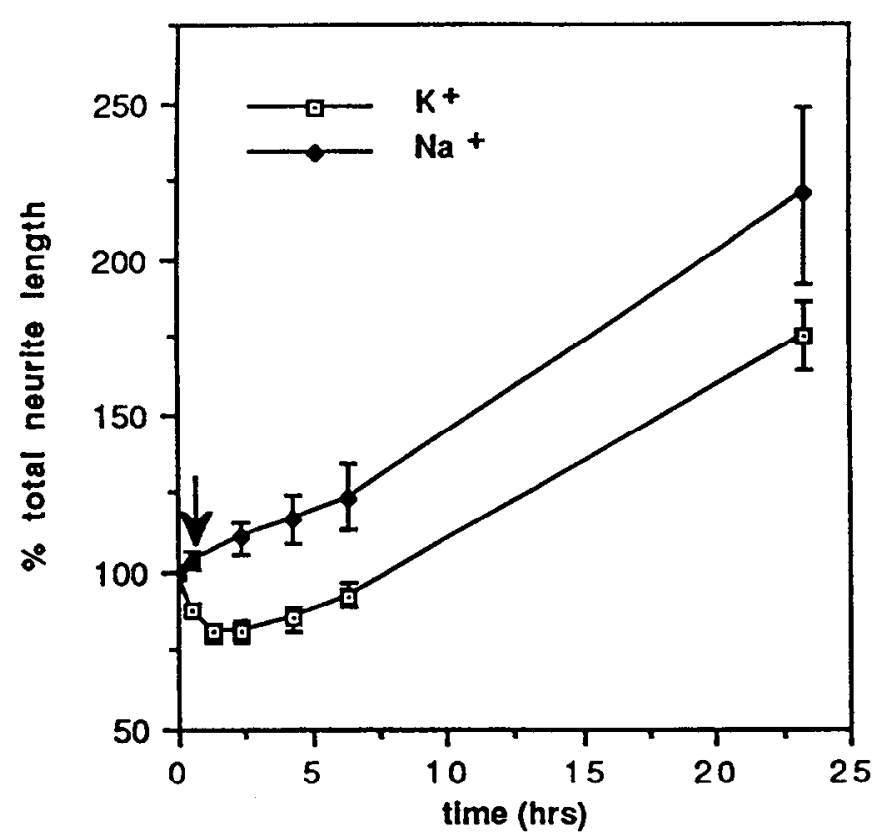

Figure 2. Time course of depolarization-induced neurite retraction. Retzius and AP cells were exposed to elevated $\mathrm{K}^{+}(\mathrm{v})$ for $30 \mathrm{~min}$ and then returned to normal medium (arrow; $n=65$ ). Control cells were exposed to $\mathrm{Na}^{+}$control medium $(\diamond)(n=15)$. Total neurite lengths were measured at the times indicated and normalized to the total starting neurite length at time 0 . Points represent mean \pm SEM.

tamicin sulfate $(0.1 \mathrm{mg} / \mathrm{ml}$ Garamycin; Essex Chemie AG, Lucerne, Switzerland), glutamine $(2 \mathrm{mM})$, glucose $(6 \mathrm{mg} / \mathrm{ml})$, and $2 \%$ fetal calf serum (GIBCO) for $1 \mathrm{hr}$ at room temperature. Individual Retzius and anterior pagoda (AP) cells were then removed by suction and plated in microwell culture dishes (Nunc) previously coated either with ConA ( 2 $\mathrm{mg} / \mathrm{ml}$ ) for $2 \mathrm{hr}$ or with a laminin-enriched EDTA extract of leech extracellular matrix (ECM) (prepared as described in Chiquet et al., 1988) for 4-16 hr. The cells were cultured for $1-6 \mathrm{~d}$ at room temperature in L-15 medium with the supplements described above.

$\mathrm{The}^{+}, \mathrm{Ca}^{2+}, \mathrm{Mg}^{2+}$, and $\mathrm{Na}^{+}$concentrations in normal $\mathrm{L}-15 \mathrm{me}-$ dium are $5.8 \mathrm{~mm}, 1.3 \mathrm{~mm}, 1.8 \mathrm{~mm}$, and $145.1 \mathrm{~mm}$, respectively. High $K^{+}$medium was prepared by adding isosmolar $\mathrm{KCl}$ and $\mathrm{CaCl}_{2}$ solutions to the medium to final concentrations of $60 \mathrm{~mm}$ for $\mathrm{K}^{+}$and $6 \mathrm{~mm}$ for $\mathrm{Ca}^{2+}$. To control for the resulting dilution of the medium, $\mathrm{Na}^{+}$control medium was prepared by adding isosmolar $\mathrm{NaCl}$ (containing $5.8 \mathrm{mM}$ $\mathrm{KCl}$ ) and $\mathrm{CaCl}_{2}$ solutions to normal medium; final concentrations were $152.4 \mathrm{~mm}$ for $\mathrm{Na}^{+}$and $6 \mathrm{mM}$ for $\mathrm{Ca}^{2+}$. High $\mathrm{K}^{+}$, high $\mathrm{Mg}^{2+}$ medium was prepared by adding isosmolar $\mathrm{KCl}$ and $\mathrm{MgCl}_{2}$ to final concentrations of $60 \mathrm{~mm}$ and $20 \mathrm{~mm}$ for $\mathrm{K}^{+}$and $\mathrm{Mg}^{2+}$, respectively.

Determination of neurite length and statistical methods. Cells were observed by phase-contrast microscopy using a Leitz-Diavert microscope with a photo camera as well as by vidco analysis using a LeitzLabovert FS microscope equipped with an MTI CCD72 video camera (Dage-MTI, Inc., Michigan City, IN). The software used to measure neurite length was IMAGE-I (Universal Imaging).

Total neurite length was determined for each cell at different times during the experiment and normalized to the total starting neurite length, which was defined as $100 \%$. Multiple exchanges of medium sometimes caused the neurites to detach from the substrate. In these cells, retraction was usually $100 \%$ and the cells did not recover. Therefore, only cells that grew at least $10 \%$ during the recovery phase were used for analysis. Seventy-three percent of the cells treated with high-K+ $K^{+}$edium and $75 \%$ of the cells exposed to $\mathrm{Na}^{+}$control medium showed more than $10 \%$ regrowth during the recovery phase. An unpaired two-tailed Student's $t$ test was used for statistical analysis of these experiments. In some experiments cells were scored as retracting or nonretracting. A ccll was considered a retracting cell when its neurite length was reduced by at least $10 \%$ of the total starting neurite length. For these experiments the $2 \times 2$ contingency table test was used for statistical analysis.
Scanning electron microscopy. To prepare the cells for observation with the scanning electron microscope (SEM), they were first fixed for $18 \mathrm{~min}$ in $0.4 \%$ paraformaldehyde, $0.6 \%$ glutaraldehyde in phosphatebuffered saline (PBS) at room temperature. After washing the cells $4 \times$ 5 min with PBS followed by $3 \times 3 \mathrm{~min}$ with distilled water, they were dehydrated in increasing concentrations of ethanol. Critical point drying was performed in a critical point dryer (Balzers Union) with liquid $\mathrm{CO}_{2}$. The cells were vacuum coated with a $20-35 \mathrm{~nm}$ layer of gold in a sputtering device designed by Balzers Union and observed with a $\mathrm{Hi}$ tachi S-800 scanning electron microscope at $20 \mathrm{kV}$.

\section{Results}

\section{Time course of depolarization-induced neurite retraction}

Leech Retzius and AP neurons that had been in culture for 1$4 \mathrm{~d}$ on ECM and were extensively growing were depolarized by raising the extracellular $\mathrm{K}^{+}$concentration from $5.8 \mathrm{~mm}$ to 60 mM. Intracellular recordings showed that high $\mathrm{K}^{+}$depolarized the membrane from $-45 \mathrm{mV}$ to $-15 \mathrm{mV}$ (data not shown). An exposure of $30 \mathrm{~min}$ to raised extracellular $\mathrm{K}^{+}$stopped ncurite outgrowth and induced neurite retraction. Figure $1 A$ shows a Retzius cell $1 \mathrm{~d}$ after plating on ECM that had shown extensive neurite outgrowth. Thirty minutes of exposure to $60 \mathrm{~mm} \mathrm{~K} \mathrm{~K}^{+}$ resulted in marked changes. Neurite extension ceased completely. Growth cones were observed to round up and neurite retraction began after 15-20 min of exposure to high $\mathrm{K}^{+}$. After return to normal medium, neurites continued to retract for a further $1.5 \mathrm{hr}$. The first signs of regrowth appeared after $3.5 \mathrm{hr}$. After $22.5 \mathrm{hr}$ of recovery the cell had regrown extensively to a total neurite length that exceeded the total starting process length. Cells treated with medium diluted with the same amount of an isosmotic $\mathrm{Na}^{+}$solution $\left(\mathrm{Na}^{+}\right.$control medium) did not retract, but continued to extend neurites (Fig. $1 B$ ).

Figure 2 shows the results for 65 Retzius and AP cells exposed to $60 \mathrm{~mm} \mathrm{~K}^{+}$for $30 \mathrm{~min}$. Maximal retraction was observed in the time between $30 \mathrm{~min}$ and $1.5 \mathrm{hr}$ of recovery. At these times the mean total neurite lengths were $80.8 \pm 2.6 \%$ and $80.1 \pm$ $3.1 \%$ of the total starting neurite length, respectively. After 22.5 hr the neurites had grown back to a mean total neurite length of $175.1 \pm 11 \%(n=65)$. Cells exposed to $\mathrm{Na}^{+}$control medium did not retract, but continued to grow $(n=15)$. The difference between total relative neurite length of cells treated with high $\mathrm{K}^{+}$medium and of cells in $\mathrm{Na}^{+}$control medium was statistically highly significant at all times $(p<0.01)$ except at $23.5 \mathrm{hr}(p<$ $0.09)$.

Exposures to high $\mathrm{K}^{+}$longer than 30 min were not more effective. Neurons in culture that were exposed to high $\mathrm{K}^{+}$for $4 \mathrm{hr}$ showed mean relative neurite lengths of $85.4 \pm 2.7 \%$ after $2 \mathrm{hr}$ and $85.3 \pm 2.8 \%$ after $4 \mathrm{hr}$ exposure. After $22.5 \mathrm{hr}$ of recovery the cells had regrown to a mean neurite length of 116.8 $\pm 4.9 \%(n=26)$ with a growth rate that was comparable to the growth rate of control cells $(n=11)$ (data not shown).

\section{Comparison of depolarization-induced neurite retraction in Retzius and AP neurons}

A comparison was made of the responses of Retzius and AP cells exposed to high $\mathrm{K}^{+}$medium for $30 \mathrm{~min}$. No significant differences were seen between the two cell types. Maximal retractions were observed to $78.1 \pm 3.3 \%$ of the total starting neurite length $(n=42)$ for Retzius cells and $79.8 \pm 5.7 \%(n=$ $23)$ for AP cells. Longer exposures of Retzius cells $(n=21)$ and AP cells $(n=22)$ to high $\mathrm{K}^{+}$also showed no differences (data not shown). 

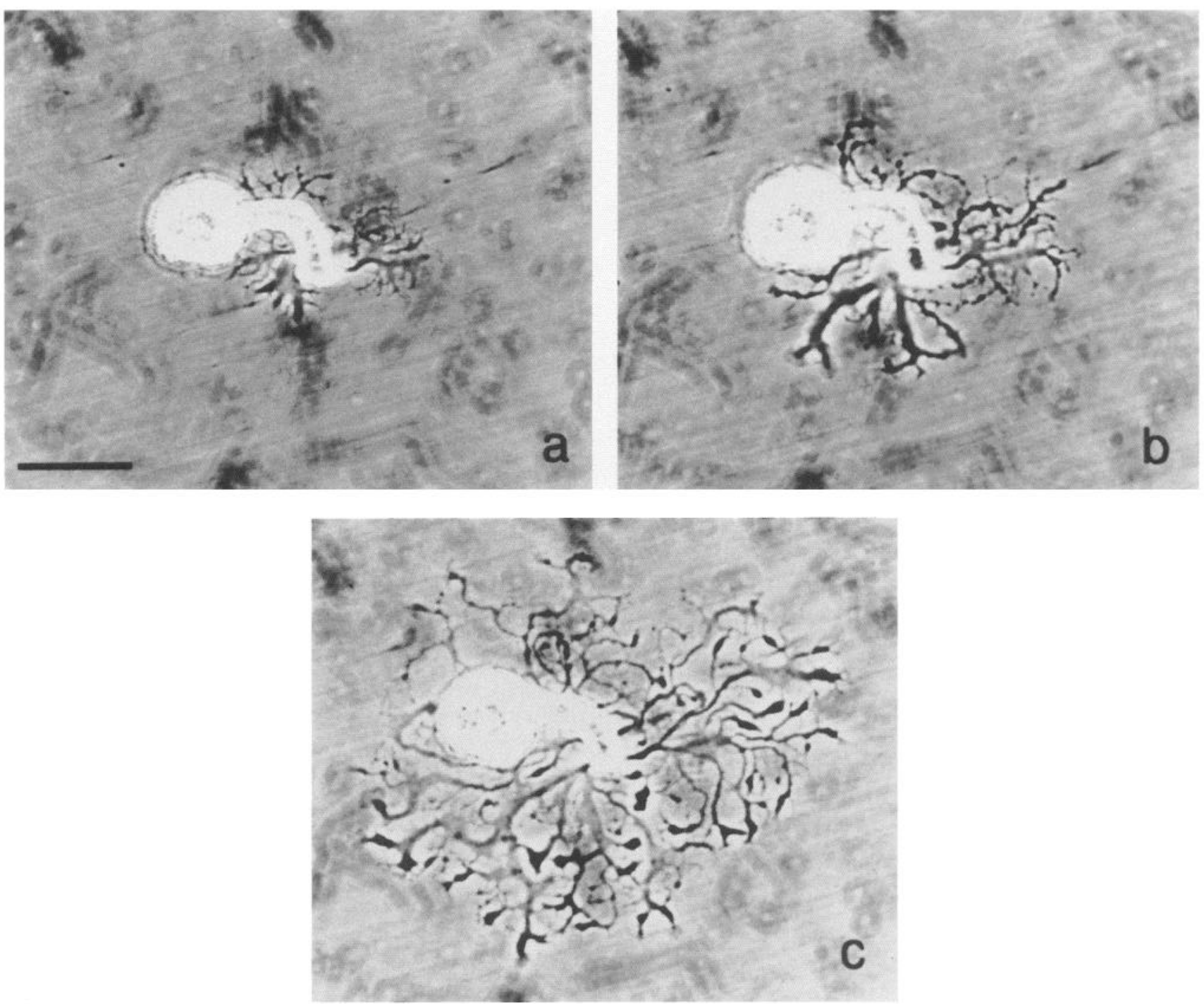

Figure 3. Depolarization does not induce neurite retraction in cells on ConA. An AP cell that had been in culture for $6 \mathrm{hr}$ in normal medium (a) was photographed after an additional $4 \mathrm{hr}$ in high $\mathrm{K}^{+}$medium $(b)$. During this time the cell continued to grow. The medium was then changed back to normal medium and neurite elongation continued during a $14 \mathrm{hr}$ recovery phase $(c)$. Scale bar, $100 \mu \mathrm{m}$.

\section{Depolarization-induced neurite retraction is substrate dependent}

To assess the role played by the substrate in the response of neurons to depolarization, cells plated on ConA were exposed to high $\mathrm{K}^{+}$. Figure 3 shows an AP cell that was exposed to high $\mathrm{K}^{+}$medium for $4 \mathrm{hr}$. During the high $\mathrm{K}^{+}$exposure, extensive outgrowth was observed, which continued during the following $14 \mathrm{hr}$ in normal medium. The same behavior was observed for Retzius and AP cells. Only $7.7 \%$ of cells on ConA reacted with neurite retraction after a $2 \mathrm{hr}$ depolarization with high $\mathrm{K}^{+}$medium $(n=26)$ (Fig. 4). The response of these cells was significantly different from the observations on cells plated on ECM, where $60.5 \%$ showed retraction after a $2 \mathrm{hr}$ depolarization $(n=$ $43, p<0.01)$, but not significantly different from cells on ECM treated with $\mathrm{Na}^{+}$control medium $(n=25)$.

To analyze the substrate-dependent behavior at the level of the growth cones, cells plated on ECM or ConA were photographed at the light microscopic level before (Figs. 5A,6A) and after (Figs. $5 B, 6 B$ ) exposure to high $\mathrm{K}^{+}$medium for $30 \mathrm{~min}$ and then processed immediately for SEM. Growth cones of control cells plated on ECM were small, $5-10 \mu \mathrm{m}$ in diameter, and had numerous filopodia (Fig. $5 C$ ). On neurites that had retracted after high $\mathrm{K}^{+}$exposure, a retraction bulb and retraction fiber were observed (Fig. 5D). Even on neurites that had not retracted, many of the growth cones were rounded up and the number of filopodia was reduced (Fig. $5 E$ ). Growth cones of cells plated on ConA in control medium were more spread out than growth cones on ECM (Fig. 6C). No differences could be observed between growth cones on ConA exposed to high $\mathrm{K}^{+}$ medium (Fig. $6 D, E$ ) or to $\mathrm{Na}^{+}$control medium (Fig. $6 C$ ). No loss of filopodia was apparent, nor was there any rounding up of the lamellipodia in depolarized cells (Fig. 6D,E).

\section{Neurite retraction depends on $\mathrm{Ca}^{2+}$ entry}

Calcium channel distribution on the growth cones of leech neurons depends on the substrate. Neurites of cells plated on ECM show $\mathrm{Ca}^{2+}$ currents after electrical stimulation, whereas those growing on ConA have no measurable $\mathrm{Ca}^{2+}$ currents (Ross et al., 1987, 1988). Several studies have suggested that experi- 


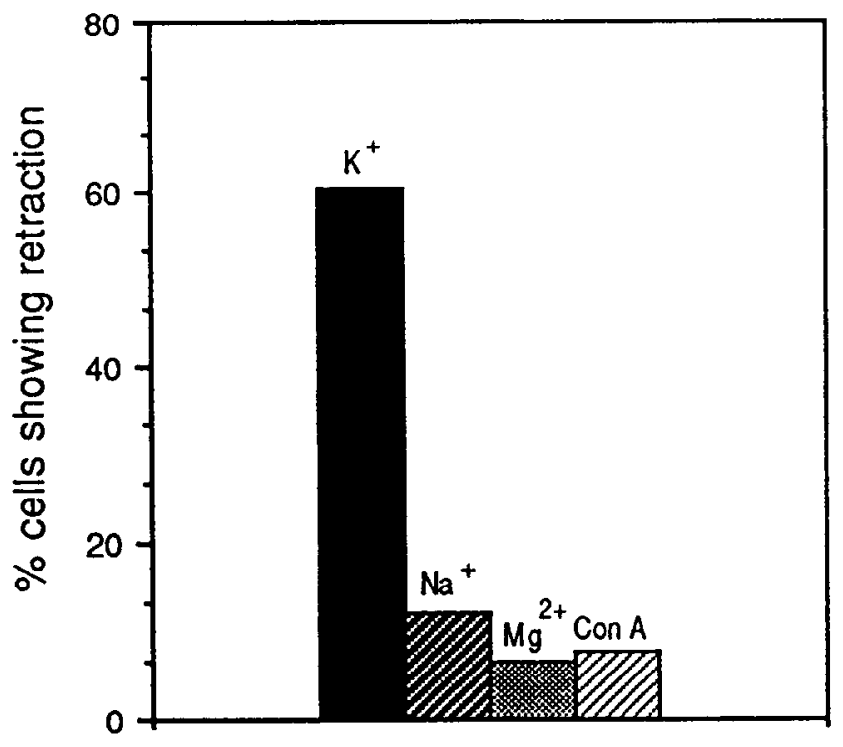

Figure 4. Retraction of leech neurons after $2 \mathrm{hr}$ of depolarization. Retzius and AP cells cultured on ECM were exposed to either high $\mathrm{K}^{+}$ medium ( $n=43)$, $\mathrm{Na}^{+}$control medium $(n=25)$, or high $\mathrm{K}^{+}$, high $\mathrm{Mg}^{2+}$ medium $(n=15)$. Of the cells exposed to high $\mathrm{K}^{+}$medium, $60.5 \%$ showed at least $10 \%$ retraction, whereas only $12.0 \%$ of the cells exposed to $\mathrm{Na}^{+}$control medium and $6.7 \%$ of cells cxposcd to high $\mathrm{K}^{+}$, high $\mathrm{Mg}^{2+}$ medium responded with retraction. Of cells growing on ConA, $7.7 \%$ showed at least $10 \%$ retraction after exposure to high $\mathrm{K}^{+}$medium $(n=26)$. See Results for statistic analysis.

mentally induced neurite retraction in cultured cells might be mediated by raised intracellular $\mathrm{Ca}^{2+}$ (Cohan et al., 1987; Mattson and Kater, 1987; Kater et al., 1988; Mattson et al., 1988). Blocking $\mathrm{Ca}^{2+}$ channels reduced, but did not abolish, retraction in leech Retzius cells that had been electrically stimulated (Grumbacher-Reinert and Nicholls, 1992).

To address the question of the role that $\mathrm{Ca}^{2+}$ plays in the depolarization-induced neurite retraction of leech neurons, I analyzed the effect of high extracellular $\mathrm{Mg}^{2+}$ on their response to high extracellular $\mathrm{K}^{+}$. Elevated $\mathrm{Mg}^{2+}$ was chosen as a $\mathrm{Ca}^{2+}$ channel blocker since dihydropyridines do not affect leech channels and inorganic ions such as $\mathrm{Cd}^{2+}$ and $\mathrm{Mn}^{2+}$ damage leech neurons if applied for longer than a few minutes. Complete elimination of $\mathrm{Ca}^{2+}$ from the medium was not possible, because this damages leech cells (J. G. Nicholls, unpublished observation). $\mathrm{Mg}^{2+}(20 \mathrm{mM})$ in the medium blocks $\mathrm{Ca}^{2+}$ influx into leech neurons reversibly and without damaging the cells or producing other effects (Muller, 1981; Henderson, 1983). Figure 7 shows that $20 \mathrm{~mm} \mathrm{Mg}^{2+}$ inhibited the $\mathrm{K}^{+}$-induced neurite retraction and the cells continued to grow $(n=13)$, whereas the mean maximal neurite retraction after $30 \mathrm{~min}$ exposure to normal high $\mathrm{K}^{+}$medium was $21.5 \pm 6.0 \%$ of the total starting neurite length $(n=18)$. The difference of total relative neurite length of cells treated with high $\mathrm{K}^{+}$medium and of cells exposed to high $\mathrm{K}^{+}$, high $\mathrm{Mg}^{2+}$ medium was statistically significant at $0.5 \mathrm{hr}(p<0.016)$, and highly significant at $1.5 \mathrm{hr}, 2.5 \mathrm{hr}$, and $4.5 \mathrm{hr}(p<0.01)$.

Cells exposed for longer times to high $\mathrm{K}^{+}$, high $\mathrm{Mg}^{2+}$ medium also behave differently from cells exposed to high $\mathrm{K}^{+}$medium for the same time. Only $6.6 \%$ of the cells treated with high $\mathrm{K}^{+}$, high $\mathrm{Mg}^{2+}$ medium for $2 \mathrm{hr}$ responded with retraction $(n=15)$, compared to $60.5 \%$ of the cells exposed to high $\mathrm{K}^{+}$medium for the same length of time $(n=43)$ (Fig. $4, p<0.01)$.
The effect of high $\mathrm{K}^{+}$, high $\mathrm{Mg}^{2+}$ medium on the growth cone morphology of cells on ECM was analyzed. Growth cones of an AP cell on ECM were photographed before (Fig. $8 A$ ) and after (Fig. $8 B$ ) a $30 \mathrm{~min}$ exposure that caused as expected no retraction; rather the neurites continued to elongate (Fig. $8 B$, arrowheads). No loss of filopodia or rounding up of growth cones was observed (Fig. 8C). Many of the growth cones showed a flattened morphology (Fig. 8C), when compared to control cells on ECM (Fig. 5C).

\section{Discussion}

This study extends work on the substrate control of neurite outgrowth in cultured leech neurons (Chiquet and Acklin, 1986; Chiquet and Nicholls, 1987). In earlier studies the overall effects of electrical stimulation and the influence of the substrate were analyzed on whole cells (Grumbacher-Reinert and Nicholls, 1992). To follow with more precision the mechanisms by which substrate influences neurite outgrowth, it is important to know which cell organelle is affected and how it responds to stimulation on different substrates. The principal emphasis here is on responses of neuronal growth cones to depolarization including detailed morphological analysis on two different substrates.

For cells grown on ECM, depolarization with high $\mathrm{K}^{+}$led first to a rounding up of growth cones, loss of filopodia, and then to a pronounced retraction of a subset of neurites. This effect was reversible and the cells started to regrow about $3 \mathrm{hr}$ after removal of the $\mathrm{K}^{+}$. Although some variability in the strength of the response was observed in different cell cultures, the variability was not correlated with time in culture or amount of neurite outgrowth (data not shown). This was different in cells that were electrically stimulated, where only cells that had already grown extensively were sensitive to the effects of electrical activity (Grumbacher-Reinert and Nicholls, 1992). On ConA, however, depolarization had no effect on the morphology of the growth cones and indeed the neurons continued to grow indistinguishably from control cells.

These experiments were performed with two different types of leech neurons, the Retzius and AP cells. Both cell types showed the same degree and timing of retraction and recovery on ECM and continued to grow on ConA after depolarization. Therefore, the response to changes in the membrane potential seems not to be cell type specific.

What could be the mechanism for this substrate-dependent response? The differences are unlikely to be due to differential adhesiveness of the two substrates. Leech neurons, when given a choice of ECM and ConA, extend processes on both substrates with equal efficiency and with substrate-specific morphology (Chiquet and Acklin, 1986; Grumbacher-Reinert, 1989). If in fact the neurons adhere better to ConA than to ECM, then the increased adhesion does not affect the efficiency of neurite extension. Other studies have shown that strength of adhesion does not necessarily correlate with the extent of growth (Tomaselli et al., 1986; Gundersen, 1987). For example, many neurons stick strongly to polylysine, but show very reduced neurite outgrowth on this substrate (Chiquet and Acklin, 1986; Chiquet and Nicholls, 1987; Wehrle and Chiquet, 1990). The observation that cells on ConA continuc to extend neurites in the presence of high extracellular $\mathrm{K}^{+}$suggests that whatever mechanism leads to a cessation of neurite outgrowth of cells on ECM is not functional in cells on ConA.

The ability to detect a signal depends on whether appropriate receptors and channels are expressed and functional within a 

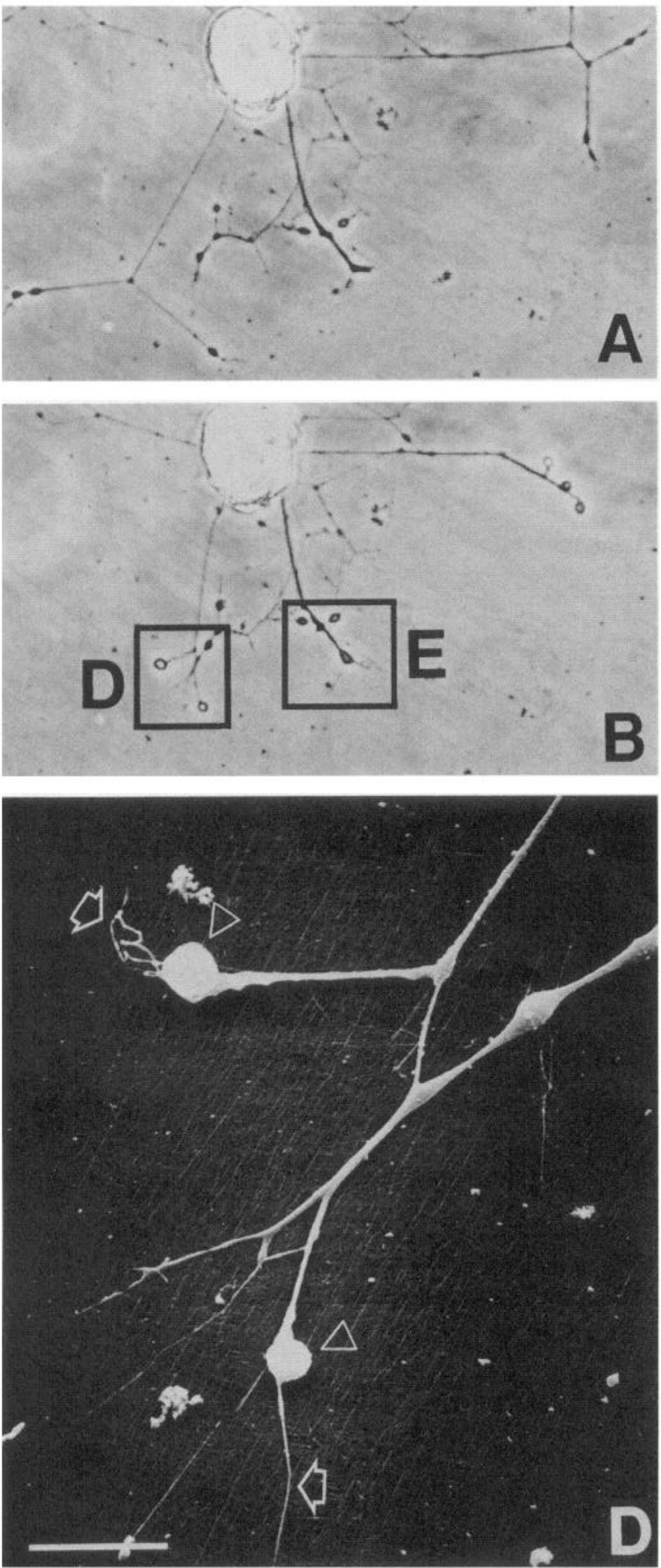

Figure 5. Morphology of growth cones of leech neurons plated on ECM after exposure to high $\mathrm{K}^{+}$medium. An AP cell that had been in culture for $1 \mathrm{~d}$ was photographed before $(A)$ and after $(B)$ a 30 min exposure to high $\mathrm{K}^{+}$medium. On neurites that had retracted, a retraction bulb $(D$, arrowheads) and retraction fiber $(D$, arrows) were usually observed. Characteristic growth cone changes of neurites that had not retracted included rounding up of lamellipodia and loss of filopodia (compare $E$ and $C ; C$ shows a growth cone in $\mathrm{Na}^{+}$control medium). $D$ and $E$ are SEM views of the boxed regions in $B$. Scale bars, $10 \mu \mathrm{m}$. 

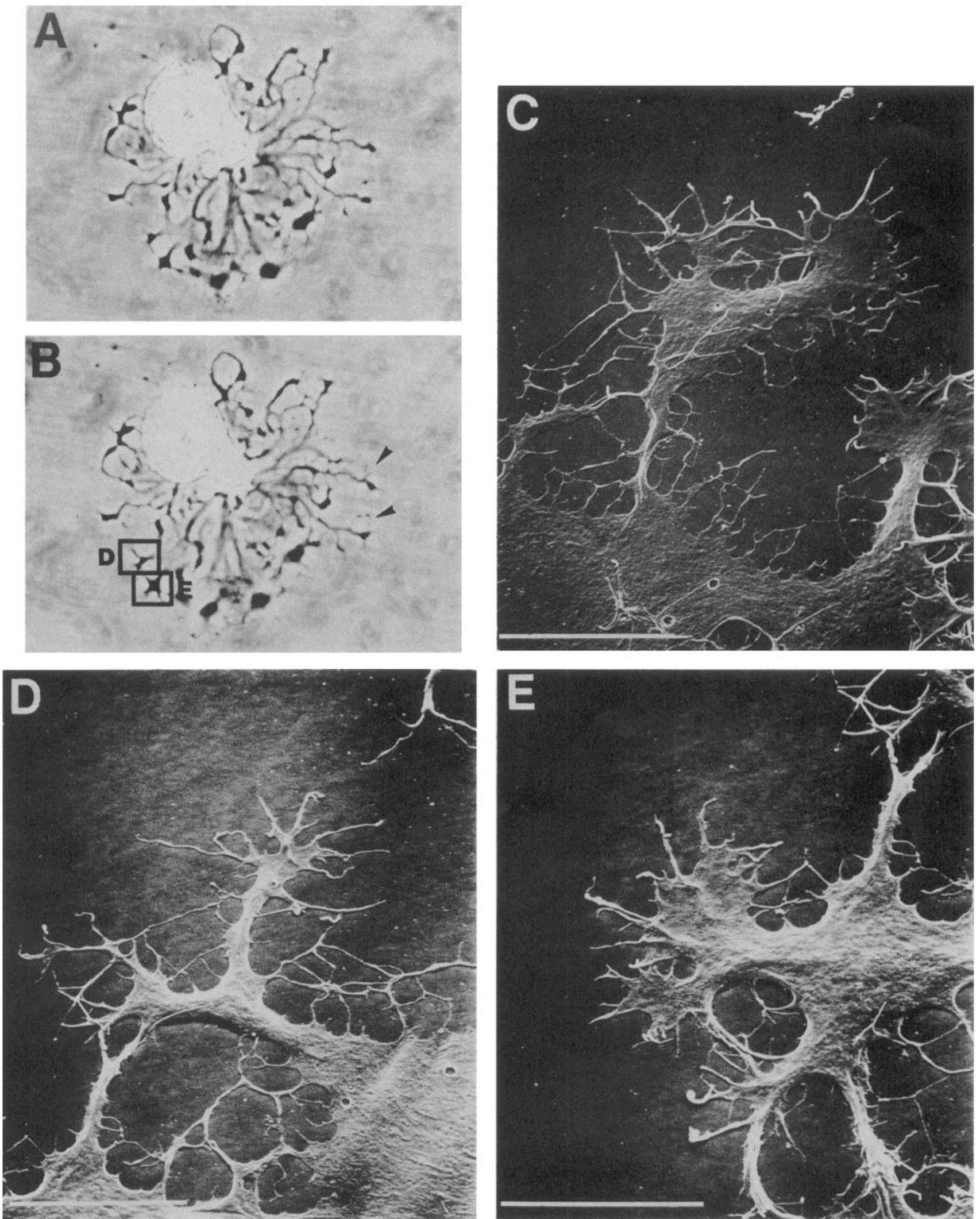

Figure 6. Morphology of growth cones of leech neurons plated on ConA and exposed to high $\mathrm{K}^{+}$. An AP neuron that had been in culture for 1 $\mathrm{d}$ was photographed before $(A)$ and $\operatorname{after}(B)$ a 30 min exposure to high $\mathrm{K}^{+}$medium. Some of the neurites grew during this treatment $(B$, arrowheads). No differences were observed between growth cones exposed to high $\mathrm{K}^{+}(D, E)$ or $\mathrm{Na}^{+}$control medium $(C)$. Broad flat growth cones, extensive lamellipodia, and many filopodia were routinely observed. $D$ and $E$ are SEM views of the boxed regions in $B$. Scale bars, $10 \mu \mathrm{m}$. 


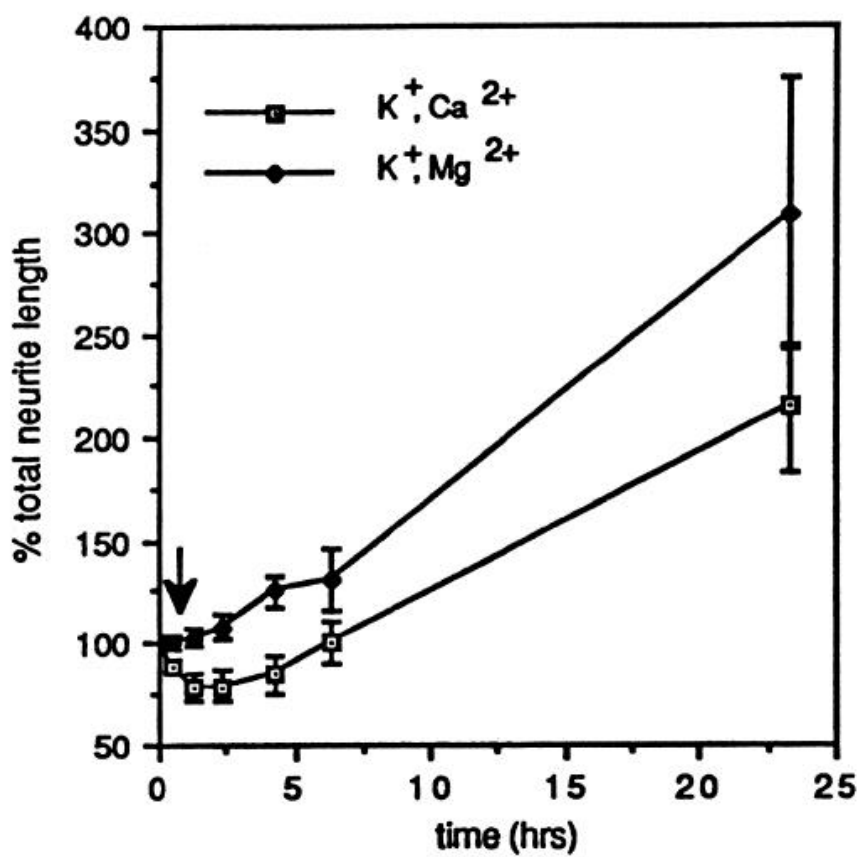

particular growth cone. I have shown here that depolarizationinduced neurite retraction depends on the influx of extracellular $\mathrm{Ca}^{2+}$. If this influx was blocked by high extracellular $\mathrm{Mg}^{2+}$, the typical changes in growth cone morphology and neurite retraction were not observed. To the contrary, some of the neurites extended farther and their growth cones had a slightly broader appearance. Retzius and AP cells growing on ECM show pronounced $\mathrm{Ca}^{2+}$ influx in their neurites following action potentials. By contrast, little or no $\mathrm{Ca}^{2+}$ entry is detectable in processes of Retzius or AP cells growing on ConA (Ross et al., 1987, 1988). These results suggest that depolarization by high extracellular $\mathrm{K}^{+}$of cells on ECM induces a $\mathrm{Ca}^{2+}$ influx through voltage-
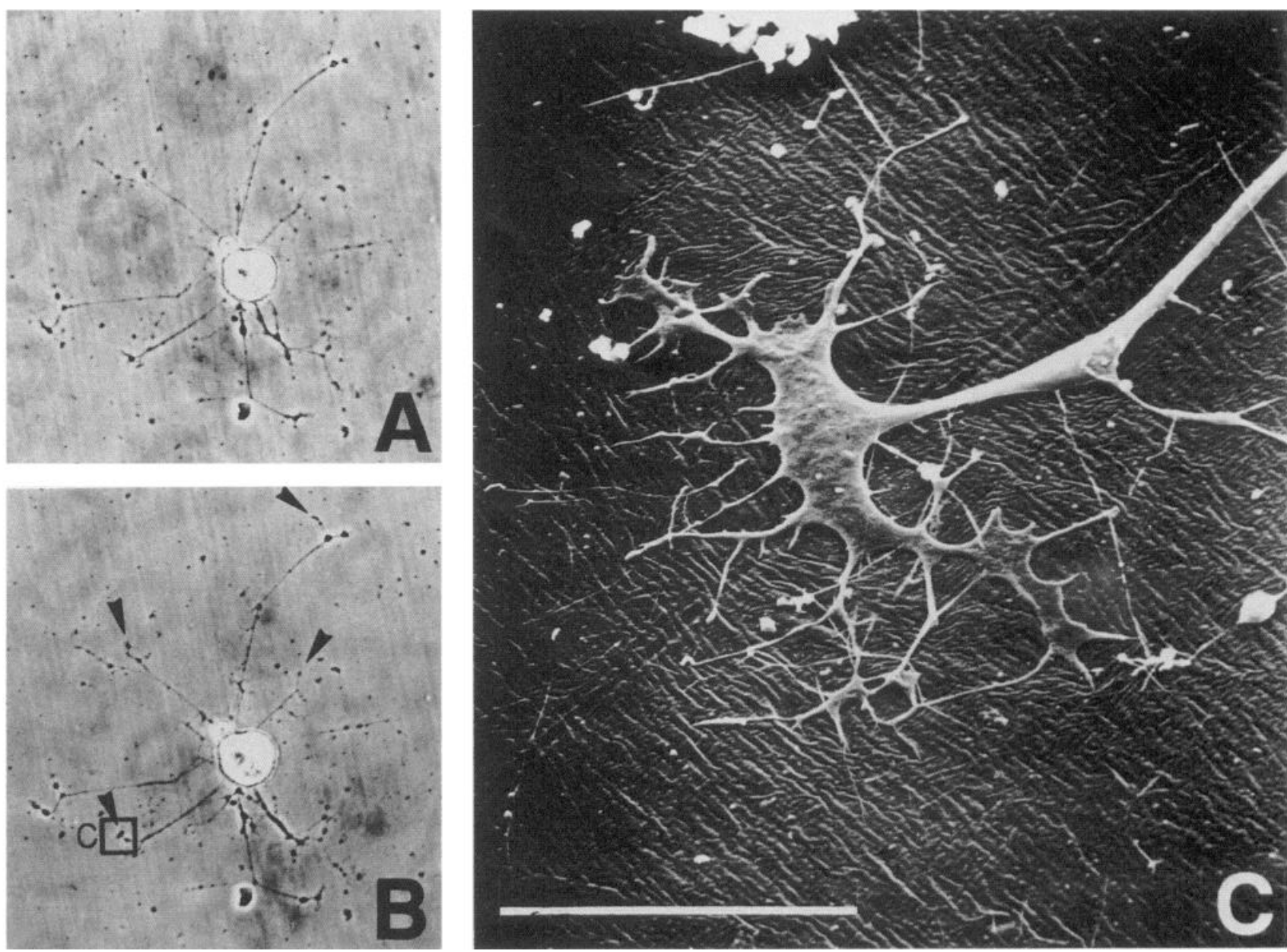

Figure 8. Morphology of growth cones on ECM exposed to high $\mathrm{K}^{+}$, high $\mathrm{Mg}^{2+}$ medium. An AP cell that had been in culture for $1 \mathrm{~d}$ was photographed before $(A)$ and $30 \mathrm{~min}$ after $(B)$ exposure to high $\mathrm{K}^{+}$, high $\mathrm{Mg}^{2+}$ medium. Some of the neurites extended farther during this treatment $(B$, arrowheads). No retraction bulbs and fibers, and no loss of filopodia or rounding up of growth cones were apparent $(C)$. The growth cones of these cells often had a more flattened broad appearance $(C)$, when compared to control cells on ECM (Fig. $6 C$ ). $C$ is an SEM view of the boxed region in $B$. Scale bar, $10 \mu \mathrm{m}$.

Figure 7. Neurite retraction induced by high $\mathrm{K}^{+}$is dependent on $\mathrm{Ca}^{2+}$ influx. Leech neurons (Retzius and AP; $n=13$ ) exposed to high $\mathrm{K}^{+}$, high $\mathrm{Mg}^{2+}$ medium $(\bullet)$ for 30 min and then returned to normal medium (arrow) did not respond with a change of growth rate and neurite retraction. Cells exposed to high $\mathrm{K}^{+}$medium () showed maximal retraction to $78.5 \%$ of the total starting neurite length $(n=18)$. Each point represents mean \pm SEM.

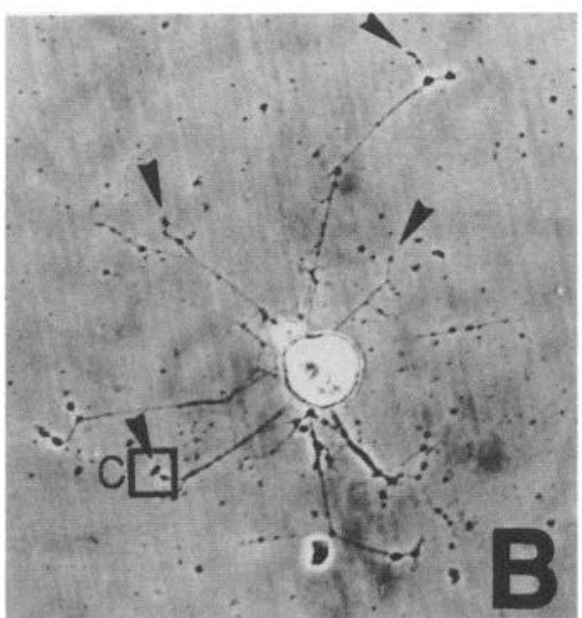


dependent $\mathrm{Ca}^{2+}$ channels. This $\mathrm{Ca}^{2+}$ influx may then be associated with neurite retraction. In cells on ConA, with no or only few $\mathrm{Ca}^{2+}$ channels and far less $\mathrm{Ca}^{2+}$ entry, no retraction is observed.

$\mathrm{Ca}^{2+}$ has been implicated in the regulation of neurite outgrowth in several other systems, although the results are contradictory. In some systems elevation of intracellular $\mathrm{Ca}^{2+}$ causes cessation of neurite outgrowth and retraction (Mattson and Kater, 1987; Mattson et al., 1988); in other systems it enhances neurite outgrowth (Anglister et al., 1982; Suarez-Isla et al., 1984) or has no effect (Campenot and Draker, 1989; Usowicz et al., 1990; Garyantes and Regehr, 1992). The range and optimal levels of calcium concentrations seem very different for different systems (Mattson and Kater, 1987).

Exactly how $\mathrm{Ca}^{2+}$ acts to change neurite outgrowth behavior is unclear for leech as well as other types of neurons. $\mathrm{Ca}^{2+}$ affects the assembly states of both microtubules (Schliwa et al., 1981) and microfilaments (Adelstein and Eisenberg, 1980; Lankford and Letourneau, 1989) and could therefore act directly upon the cytoskeleton. The earliest changes observed in this study were rounding up of growth cones and loss of filopodia. Since microfilaments are the main cytoskeletal component of the filopodia and the peripheral areas of the growth cone, they might well be a target for entering $\mathrm{Ca}^{2+}$. Experiments to test if microfilaments and other cytoskeletal components are affected by depolarization are in progress.

It is, however, also possible that $\mathrm{Ca}^{2+}$ acts more indirectly by influencing other second messenger systems. Recent studies have suggested an involvement of other second messengers in the $\mathrm{Ca}^{2+}$-dependent change of neurite outgrowth (Reboulleau, 1986; Polak et al., 1991). High $\mathrm{K}^{+}$has been shown to induce a change in the expression of cytoskeletal proteins (Riederer et al., 1992). The influence of the substrate on $\mathrm{K}^{+}$-induced change in gene expression is not known, but the substrate under normal conditions has been shown to affect gene expression (Acheson et al., 1986; Werb et al., 1989; Ben-Ze'ev, 1991). The delay of 20 min between the start of depolarization and the beginning of the first changes in growth cone morphology suggests that events subsequent to $\mathrm{Ca}^{2+}$ entry are complex and involve several steps.

There remains the question of whether the observed change in neurite outgrowth after depolarization of adult leech neurons in culture is physiologically significant. The response of leech ncurons to depolarization with high extracellular $\mathrm{K}^{+}$observed in these studies was in many aspects similar to the response of Retzius cells stimulated with extracellular electrodes (Grumbacher-Reinert and Nicholls, 1992). The use of high extracellular $\mathrm{K}^{+}$to depolarize cells has several advantages over electrical stimulation. Stimulation of cells with extracellular tungsten electrodes is difficult to perform, and only a limited number of cells can be stimulated at a time. Neurite retraction is a phenomenon also observed during the normal development of the leech nervous system (Wallace, 1984; Gao and Macagno, 1987a,b). In the adult animal, leech neurons start sprouting after injury and target removal and stop growing when they reach their target (Scott and Muller, 1980; Mason and Muller, 1982). Leech neurons that have been removed from the ganglion and put into culture also start to sprout extensively. In addition, leech neurons in vitro retain many of their in vivo properties (Fuchs et al., 1981; Arechiga et al., 1986; Vyklicky and Nicholls, 1988; Stewart et al., 1989; Acklin and Nicholls, 1990). This substratedependent response of leech neurons in culture to depolarization therefore provides us with a valuable system to study one mech- anism by which the substrate influences neuronal differentiation.

\section{References}

Achcson A, Edgar D, Timpl R, Thoenen H (1986) Laminin increases both levels and activity of tyrosine hydroxylase in calf adrenal chromaffin cells. J Cell Biol 102:151-159.

Acklin SE, Nicholls JG (1990) Intrinsic and extrinsic factors influencing properties and growth patterns of identified leech neurons in culture. J Neurosci 10:1082-1090.

Adelstein RS, Eisenberg E (1980) Regulation and kinetics of the actinmyosin-ATP interaction. Annu Rev Biochem 49:921-956.

Anglister L, Farber IC, Shahar A, Grinvald A (1982) Localization of voltage-sensitive calcium channels along developing neurites: their possible role in regulating neurite elongation. Dev Biol 94:351-365.

Arechiga $\mathrm{H}$, Chiquet M, Kuffler DP, Nicholls JG (1986) Formation of specific connections in culture by identified leech neurones containing serotonin, acetylcholine and peptide transmitters. J Exp Biol 126:15-31.

Baptista CA, Macagno ER (1988) Modulation of the pattern of axonal projections of a leech motor neuron by ablation or transplantation of its target. Neuron 1:949-962.

Ben-Ze'ev A (1991) Animal cell shape changes and gene expression. Bioessays 13:207-212.

Budnik, V, Zhong Y, Wu C-F (1990) Morphological plasticity of motor axons in Drosophila mutants with altered excitability. J Neurosci 10: 3754-3768.

Campenot RB (1984) Inhibition of nerve fiber regeneration in cultured sympathetic neurons by local, high potassium. Brain Res 293:159163.

Campenot RB, Draker DD (1989) Growth of sympathetic nerve fibers in culture does not require extracellular calcium. Neuron 3:733-743.

Carbonetto S, Gruver MM, Turner DC (1983) Nerve fiber growth in culture on fibronectin, collagen, and glycosaminoglycan substrates. J Neurosci 3:2324-2335.

Chiquet M, Acklin SE (1986) Attachment to Con A or extracellular matrix initiates rapid sprouting by cultured leech neurons. Proc Natl Acad Sci USA 83:6188-6192.

Chiquet M, Nicholls JG (1987) Neurite outgrowth and synapse formation by identified leech neurones in culture. J Exp Biol 132:191206.

Chiquet M, Masuda-Nakagawa L, Beck K (1988) Attachment to an endogenous laminin-like protein initiates sprouting by leech neurons. J Cell Biol 107:1 189-1198.

Cohan CS, Kater SB (1986) Suppression of neurite elongation and growth cone motility by electrical activity. Science 232:1638-1640.

Cohan CS, Haydon PG, Kater SB (1985) Single channel activity differs in growing and nongrowing growth cones of isolated identified neurons of Heliosoma. J Neurosci Res 13:285-300.

Cohan CS, Connor JA, Kater SB (1987) Electrically and chemically mediated increases in intracellular calcium in neuronal growth cones. J Neurosci 7:3588-3599.

Dietzel ID, Drapeau P, Nicholls JG (1986) Voltage dependence of 5-hydroxytryptamine release at a synapse between identified leech neurones in culture. J Physiol (Lond) 372:191-205.

Fields RD, Neale EA, Nelson PG (1990) Effects of patterned electrical activity on neurite outgrowth from mouse sensory neurons. J Neurosci 10:2950-2964.

Fuchs PA, Nicholls JG, Ready DF (1981) Membrane properties and selective connexions of identified leech neurones in culture. J Physiol (Lond) 316:203-223.

Gao W-Q, Macagno ER (1987a) Extension and retraction of axonal projections by some developing neurons in the leech depends upon the existence of neighboring homologues. I. The HA cells. J Neurobiol 18:43-59.

Gao W-Q, Macagno ER (1987b) Extension and retraction of axonal projections by some developing neurons in the leech depends upon the existence of neighboring homologues. II. The AP and AE neurons. J Neurobiol 18:295-313.

Garyantes TK, Regehr WG (1992) Electrical activity increases growth cone calcium but fails to inhibit neurite outgrowth from rat sympathetic neurons. J Neurosci 12:96-103.

Glover JC, Mason A (1986) Morphogenesis of an identified leech 
neuron: segmental specification of axonal outgrowth. Dev Biol 115: 256-260.

Goodman CS, Bate M, Spitzer NC (1981) Embryonic development of identified neurons: origin and transformation of the $\mathrm{H}$ cell. J Neurosci 1:94-102.

Grumbacher-Reinert S (1989) Local influence of substrate molecules in determining distinctive growth patterns of identified neurons in culture. Proc Nat1 Acad Sci USA 86:7270-7274.

Grumbacher-Reinert S, Nicholls J (1992) Influence of substrate on retraction of neurites following electrical activity of leech Retzius cells in culture. J Exp Biol 167:1-14.

Gundersen RW (1987) Response of sensory neurites and growth cones to patterned substrata of laminin and fibronectin in vitro. Dev Biol 121:423-431.

Hammarback JA, McCarthy JB, Palm SL, Furcht LT, Letourneau PC (1988) Growth cone guidance by substrate-bound laminin pathways is correlated with neuron-to-pathway adhesivity. Dev Biol 126:29 39.

Heathcote RD, Sargent PB (1985) Loss of supernumerary axons during neuronal morphogenesis. J Neurosci 5:1940-1946.

Henderson LP (1983) The role of 5-hydroxytryptamine as a transmitter between identified leech neurones in culture. J Physiol (Lond) 339:309-324.

Hubel DH, Wiesel TN (1970) The period of susceptibility to the physiological effects of unilateral eye closure in kittens. J Physiol (Lond) 206:419-436.

Innocenti GM (1981) Growth and reshaping of axons in the establishment of visual callosal connections. Science 212:824-827.

Jellies J, Loer CM, Kristan WB (1987) Morphological changes in leech Retzius neurons after target contact during embryogenesis. J Neurosci 7:2618-2629.

Kater SB, Mattson MP, Cohan C, Connor J (1988) Calcium regulation of the neuronal growth cone. Trends Neurosci 11:315-321.

Kuwada JY, Kramer AP (1983) Embryonic development of the leech nervous system: primary axon outgrowth of identified neurons. J Neurosci 3:2098-2111.

Lankford KL, Letourneau PC (1989) Evidence that calcium may control neurite outgrowth by regulating the stability of actin filaments. $J$ Cell Biol 109:1229-1243.

Letourneau PC (1979) Cell-substratum adhesion of neurite growth cones, and its role in neurite elongation. Exp Cell Res 124:127-138.

Levine RB, Truman JW (1982) Metamorphosis of the insect nervous system: changes in morphology and synaptic interactions of identified neurones. Nature 299:250-252.

Levine RB, Truman JW, Linn D, Bate CM (1986) Endocrine regulation of the form and function of axonal arbors during insect metamorphosis. J Neurosci 6:293-299.

Lnenicka GA, Murphey RK (1989) The refinement of invertebrate synapses during development. J Neurobiol 20:339-355.

Loer CM, Jellies J, Kristan WB (1987) Segment-specific morphogenesis of leech Retzius neurons requires particular peripheral targets. J Neurosci 7:2630-2638.

Mariani J, Changeux J-P (1981) Ontogenesis of olivocerebellar relationships. I. Studies by intracellular recordings of the multiple innervation of Purkinje cells by climbing fibers in the developing rat cerebellum. J Neurosci 1:696-702.

Mason A, Muller KJ (1982) Axon segments sprout at both ends: tracking growth with fuorescent D-peptides. Nature 296:655-657.

Mattson MP, Kater SB (1987) Calcium regulation of neurite elongation and growth cone motility. J Neurosci 7:4034-4043.

Mattson MP, Dou P, Kater SB (1988) Outgrowth-regulating actions of glutamate in isolated hippocampal pyramidal neurons. J Neurosci 8:2087-2100.

Muller KJ (1981) Synapses and synaptic transmission. In: Neurobiology of the leech (Muller KJ, Nicholls JG, Stent GS, eds), pp 79111. Cold Spring Harbor, NY: Cold Spring Harbor Laboratory.

Pipa RL (1978) Patterns of neural reorganization during the postembryonic development of insects. Int Rev Cytol [Suppl] 7:403-438.

Polak KA, Edelman AM, Wasley JWF, Cohan CS (1991) A novel calmodulin antagonist, CGS 9343B, modulates calcium-dependent changes in neurite outgrowth and growth cone movements. J Neurosci 11:534-542.

Purves D, Lichtman JW (1980) Elimination of synapses in the developing nervous system. Science 210:153-157.
Reboulleau CP (1986) Extracellular calcium-induced neuroblastoma cell differentiation: involvement of phosphatidylinositol turnover. $J$ Neurochem 46:920-930.

Reichardt LF, Tomaselli KJ (1991) Extracellular matrix molecules and their receptors: functions in neural development. Annu Rev Neurosci 14:531-570.

Riederer BM, Monnet-Tschudi F, Honegger P (1992) Development and maintenance of the neuronal cytoskeleton in aggregated cell cultures of fetal rat telencephalon and influence of elevated $\mathrm{K}^{+}$concentrations. J Neurochem 58:649-658.

Rivas RJ, Burmeister DW, Goldberg DJ (1992) Rapid effects of laminin on the growth cone. Neuron 8:107-115.

Robson SJ, Burgoyne RD (1989) L-type calcium channels in the regulation of neurite outgrowth from rat dorsal root ganglion neurons in culture. Neurosci Lett 104:110-114.

Ross WN, Arechiga H, Nicholls JG (1987) Optical recording of calcium and voltage transients following impulses in cell bodies and processes of identified leech neurons in culture. J Neurosci 7:38773887.

Ross WN, Arechiga H, Nicholls JG (1988) Influence of substrate on the distribution of calcium channels in identified leech neurons in culture. Proc Natl Acad Sci USA 85:4075-4078.

Sanes JR (1989) Extracellular matrix molecules that influence neural development. Annu Rev Neurosci 12:491-516.

Schliwa M, Euteneuer U, Bulinski JC, Izant JG (1981) Calcium lability of cytoplasmic microtubules and its modulation by microtubule-associated proteins. Proc Natl Acad Sci USA 78:1037-1041.

Scott SA, Muller KJ (1980) Synapse regeneration and signals for directed axonal growth in the central nervous system of the leech. Dev Biol 80:345-363.

Shatz CJ (1990) Impulse activity and the patterning of connections during CNS development. Neuron 5:745-756.

Stewart RR, Nicholls JG, Adans WB (1989) $\mathrm{Na}^{+}, \mathrm{K}^{+}$and $\mathrm{Ca}^{2+}$ currents in identified leech neurones in culture. $J$ Exp Biol 141:1-20.

Suarez-Isla BA, Pelto DJ, Thompson JM, Rapoport SI (1984) Blockers of calcium permeability inhibit neurite extension and formation of neuromuscular synapses in cell culture. Dev Brain Res 14:263-270.

Sussdorf WS, Campenot RB (1986) Influence of the extracellular potassium environment on neurite growth in sensory neurons, spinal cord neurons and sympathetic neurons. Dev Brain Res 25:43-52.

Tomaselli KJ, Reichardt LF, Bixby JL (1986) Distinct molecular interactions mediate neuronal process outgrowth on non-neuronal cell surfaces and extracellular matrices. J Cell Biol 103:2659-2672.

Truman JW, Reiss SE (1976) Dendritic reorganization of an identified motoneuron during metamorphosis of the tobacco hornworm moth. Science 192:477-479.

Usowicz MM, Porzig H, Becker C, Reuter H (1990) Differential expression by nerve growth factor of two types of $\mathrm{Ca}^{2+}$ channels in rat phaeochromocytoma cell lines. J Physiol (Lond) 426:95-116.

Van Essen DC (1982) Neuromuscular synapse elimination: structural, functional, and mechanistic aspects. In: Neuronal development (Spitzer NC, ed), pp 333-376. New York: Plenum.

Vyklicky L, Nicholls J (1988) Specificity of connections formed by nociceptive cells of the leech in tissue culture. J Exp Biol 134:17-26.

Wallace BG (1984) Selective loss of neurites during differentiation of cells in the leech central nervous system. J Comp Neurol 228:149153.

Wehrle B, Chiquet M (1990) Tenascin is accumulated along developing peripheral nerves and allows neurite outgrowth in vitro. Development $110: 401-415$.

Werb Z, Tremble PM, Behrendtsen O, Crowley E, Damsky CH (1989) Signal transduction through the fibronectin receptor induces collagenase and stromelysin gene expression. J Cell Biol 109:877-889.

Wiesel TN, Hubel DH (1963) Effects of visual deprivation on morphology and physiology of cells in the cat's lateral geniculate body. $J$ Neurophysiol 26:978-993.

Wiesel TN, Hubel DH (1965) Comparison of the effects of unilateral and bilateral eye closure on cortical unit responses in kittens. J Neurophysiol 28:1029-1040.

Wolszon LR, Macagno ER (1992) Growth cone interactions and the patterns of peripheral innervation in the leech. In: The nerve growth cone (Letourneau PC, Kater SB, Macagno ER, eds), pp 305-322. New York: Raven. 